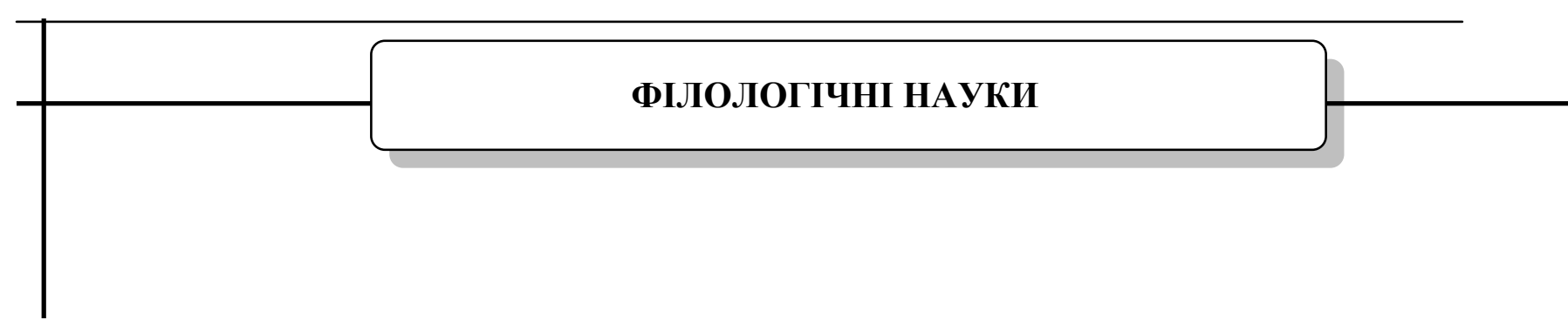

УДК: 811: 111: 81'373.7:81'42

DOI: $10.15587 / 2313-8416.2016 .72031$

\title{
MECHANISMS OF IDIOMATIC TRANSFORMATIONS CREATING IN CONTEMPORARY ENGLISH ADVERTISING DISCOURSE
}

\section{(C) O. Makedonova}

This article deals with phraseological transformations in English advertising discourse. It was determined that all phraseological transformations can be divided into two types: semantic and structural-semantic. Semantic transformations are formed by mechanisms of dephraseologisation and dual actualization. Structural-semantic transformations are made up by components expanding of original set expressions which realized due to enlargement and wedging, reduction of compositional component by "truncation" and substitution of components Keywords: advertising discourse, phraseological transformations, semantic transformations, structural-semantic transformations

Стаття присвячена аналізу трансформацій ФО у англомовному рекламному дискурсі. Виявлено, щзо фразеологічні трансформацї можливо поділити на два види: семантичні $і$ структурно-семантичні. Семантичні трансформації у дискурсі англомовної реклами утворюються за допомогою механізмів дефразеологізації і амбівалентної актуалізації семантики. Структурно-семантичні модифікації формуються шляхом застосування трьох механізмів: розширення, скорочення компонентного складу ФО і субституиії структурних компонентів узуального фразеологізму

Ключові слова: рекламний дискурс, фразеологічні трансформачї, семантичні трансформацї, лексикосемантичні трансформації

\section{Introduction}

The use of phraseological transformations in English advertising discourse is an effective means of pragmatic impact on a recipient. Persuasion of an advertisment receiver is achieved due to synchronic actualization of direct and figurative meanings in an advertising text. Such functioning can be used as evaluative effect to influence the recipient's mind and endue the advertising goods or services with positive characteristics.

The multiplicity and diversity of phraseological transformations in English are evident, but the problem of the classification and creating mechanisms in advertising discourse needs detailed analysis and consideration. With considerable number of phraseological transformations in English advertising discourse, there is a problem of identifying the creative mechanisms, which in fact determines the actuality of current research.

\section{Literature review}

The analysis of theoretical literature concerning idiomatic transformations has shown that this phenomenon is becoming a subject of linguists' research.The area of linguistic interest labeled as transformations were proven to have a pragmatic effect to influence an addressee.
For the last decades, there have been conducted numerous studies on different aspects of idiomatic transformations. The series of works are dedicated to variations of phraseological units in different discourses [1]. Some works are devoted to a substitution as one of the type of phraseological transformations [2], [3]. The significant researches have been conducted on the phraseological synonymous creations [4] and usual phraseologisms in discourse of advertising [5].

All these researches don't give the deep understanding of conceptual changes and procedures that semantic and structural-semantic transformations of phraseological units, as well as and the understanding of relationship between the modified utterance and the original phraseological units in order to define mechanisms of creating in English advertising discourse.

\section{Aim and research problems}

The concrete aim of an article is to reveal the mechanisms of idiomatic transformations and their functional features in English advertising texts. To achieve this aim, we are going to solve the following specific tasks:

- To define mechanisms of transformations creating;

- to reveal their functional peculiarities;

- to highlight pragmatic effect of idioms. 


\section{Mechanisms of phraseological transforma- tions creating}

Taking as a basis the broad understanding of phraseology as any set expression, we refer to phraseological units all fixed phrases and paroemic units. Exploring phraseological units functions on the pages of commercial advertisements, we determinate between the established units in the language and created in the concrete speech. We understand occasional transformations as changes in expressions structure and semantics (or only in semantics) which are a result of phraseological unit incorporation in the context of advertising copy to create expressive and stylistic effect [6].

The use of occasional phraseological units in English advertising texts is explained by their ability to define such an object, which can not be expressed by the established use [3].

Currently, there is no generally accepted scientific classification of set expressions' transformations, but they are classified according to its deviation from traditional forms and semantics. It is supposed that all transformations are divided into two types: semantic and structural -semantic transformations [3].

Semantic transformations include changes which do not affect the lexical and grammatical structure of phraseological units. Structural-semantic modifications are associated with changing of vocabulary and grammar form [3].

To be taken under consideration semantic transformation of set expressions, dephraseologisation and dual actualization of semantics are supposed to be the most commonly used mechanisms in English advertising discourse.

1. Dephraseologisation (literalization of meaning). Using this method, direct meaning of phraseological unit does not only become actual, but also stands in opposition to an idiom semantics that can be demonstrated in advertisement of a car brand Peugeot: At last, car manufacturer offering something other than hot air. Cold air. (Top Gear, April, 2010). As we can see, copywriters of Peugeot company, offering a new climate control system, used the idiom hot air "empty talk, that does not bring practical results", which, thus is realized by a recipient, but not assimilated with the general context. In opposition to idiomatic semantics, in fact, it is clearly observed literal meaning of lexical unit, defined as empty promises of competitive companies.

2. Dual actualization of semantics is defined as a combination of idiomatic meaning and its internal form [7]. An effectiveness of this mechanism in advertising copies can be explained by expansion of a content of idiom, because idioms' semantics are realized at the same time with its structural components, for example: «Beauty sleep» in a jar. L'oreal (Good Housekeeping, May, 2012). In the above given fragment, which advertises L'oreal night cream for face, phraseologism beauty sleep "large number of sleep hours to be healthy and attractive" realizes a dual meaning. Due to usual meaning of phraseological unit, which can be understood by a recipient, literal semantics of individual components are also reproduced in the context. At the same time we can see an effect, that a lexical unit beauty is associat- ed with night cream in the mind of the recipient, the use of which makes skin firmer and more glowing during a night sleep.

In addition, we consider that it's possible to define an intermediate device, which synthesizes dual actualization and literal meaning of components. Simultaneous realization is based on lingual mechanism of pun, the result of which is creating a paradoxical effect. An example is the advertising of deposits in Credit Suisse bank, where phraseological unit to make a killing "making money quickly without effort" [8] used twice: You do not have to make a killing to make a killing. Credit Suisse (Smart Money, March, 2012). In the first graphic form the idiom loses its phraseological meaning and stands, thus as if in opposition to the literal meaning of lexical unit, that compose this set expression. In the second case, the phraseologism is supposed to interpret correctly, providing, that we observe, a kind of paradox, which means to create a positive perception of the advertised item.

In contrast to semantic transformations, structural - semantic modifications concern grammatical and lexical structure of a phraseological unit, reducing or enlarging it, creating a new context and consequently, changing the established meaning.

Linguists, who analyze the features of advertising texts state, that in case of occasional use of phraseological units, expanding, reducing of the components or substitution of the structural components of phraseological units occur [8]. We take under consideration each mechanism of making structural - semantic transformations separately.

1. Component structure expansion of phraseological unit is based on incorporation of additional components in the composition of an idiom [2]. We define expansion of the structural components like adding elements to beginning or ending, or wedging into the middle of set espression. According to the location of the additional element, there are two ways of component structure expansion: wedging and deployment.

a) wedging is a structural - semantic mechanism, when a new element becomes a part of phraseological unit in advertising text, changes the structure and expands its component composition, for example: Be in no one's shadow. Infinity FX (Esquire, December, 2012). In a given advertising fragment of Infinity car, idiom be in one's shadow "receiving less attention than others" transformed by wedging of a negative particle no into its structure, and changed its semantics into the opposite. "Updated" idiom corresponds to the general idea of advertising message, it is adapted to the context and aimed at attracting addressee attention, purchasing the suggested product. Changing the semantics of phraseologism into the opposite does not prevent the recipient from decoding it easily in his mind, and such phraseological unit occasional form conveys the author's intention specifically and more successfully.

b) components enlargement occurs when adding lexical units into phraseological unit structure. This provides greater contreteness, adapting it to a situation where it is used in. Our research demonstrates, that enlargement device is rarely used in its original form. The 
desire to make advertising text concise and expressive leads to enlarging with a help of components "truncation", as can be seen in a following example: Head-to-toe healthcare at your fingertips. Intel (The economist, September, 2013).

Let's take such a phraseological unit from head to toe which is used with a process of omitting of preposition from, since it does not correspond to a general purpose of the whole advertisment message. In this case, we can see not only the enlargement of components omittion, but phraseological context saturation as well, that is why, an additional phraseologisms at your fingertips is used in the title of the advertising text.

Let's consider one more example of enlargement mechanism, which is used to specify the semantics of phraseological unit: Speak volumes. Words, optional. Bombey high. The color of success (GQ 2011, 12). In advertising copy of menswear brand, the heading of advertisement is an idiom speak volumes "expresses something clearly and exhaustively" [9], and next sentence does not just extend the meaning of set expression, but specifies it as well, at the same time emphasizing, that all words in the copy of the brand are needless.

It should be noted, that we can observe some examples of using enlargement mechanism, dealing with a use of several phraseological units, for instance: Vivienne has a finger on the pulse and an eye on the Planet. That's where DHL comes in. (NW, September, 2010). Such a device is explained by the senders' desire to submit the text to the recipient as distinctly as possible to increase its efficiency. The so-called "phraseological context saturation" occurs, when simultaneous use of several set expressions is possible, leading to the creation of additional associations. In the example above we can see two phraseological units have a finger on, have an eye on, which have synonymous semantics "know or monitor the situation and be ready at any moment to respond", which leads to the fact that semantics of these phraseological units is perceived as positive features of courier company DHL in recipient's mind.

Expansion of componential structure of phraseological unit by enlarging brings an additional meaning according to the purpose of the entire message, and at the same time, function as specifying content, e. g.: I used to wash my face with a bar. Then OLAY cleanser changed my tunes, beautifully. Olay Pore Minimizing cleanser + scrab (Marie Claire Feb 2012). In this case, an idiomatic expression change one's tunes "change opinion or behavior" is used in the advertising text, that is thus added by a new component. This component brings additional information, emphasizing the way in which the use of the advertised product may change a potential consumer's mind. Incorporation of lexical unit beautifully does not only specify the meaning of idiom, but also increases the expressiveness, "intimate" communicative space.

2. Reduction of componential structure of phraseological unit (phraseological ellipsis) is based on semantics and functioning "narrowing" of language phraseologcal units. This is achieved through the device of individual components "truncation" of lingual phraseologism that is motivated by the desire to make speech la- conic, to eliminate redundant components in speech situation. When using such a mechanism of phraseological transformations, the recipient reacts subconsciously to it as an existing semantics cliché in his memory, and only contextual factors indicate which part of this semantics is communicatively and situationaly relevant [1].

With the reduction of phraseological structure, a component is generally removed actually does not meet the pragmatics message, general idea of advertising text, i. e. the image of advertising products. It can be seen in such example: Weight off your shoulders and load off your mind. Lenovo. For those who do (Stuff, January, 2012). In advertisement of Lenovo ultrabook, two phraseological units be a weight off your shoulders, be a load off your mind, were taken as a basis of transformation. From the structure of the text the verb to be and the article $a$ were deleted. It is explained by advertising makers' plan to create a slogan on the basis of imperative sentence, which can be considered sufficiently effective in persuading and motivating the potential recipient. "Updated" idiom, saving language space, did not lose a common sense in this way, at the same time became more effective in a particular language situation.

3. The substitution of set expression components means a transformation device, which is based on intentional replacement of phraseological unit components with non normative elements. Note should be taken that such substitution is dependent on a specific communicative task [8].

Within substitution devices we single out specific cases of component replacements:

a) substitution of component that corresponds to brand's name, organization: Say it with Michelis. Jewellery. (Cosmo, October, 2011). As it is seen from the advertising piece mentioned above, in order to create an occasional idiom, a set expression say it with flowers "say something soft and romantic" was used. Brand name of jewelry company Michelis became a substitutive component, creating occasional expression which does not lose the primary imagery and keeps an internal form, so easily decoded in recipients' minds.

b) substitution of component that corresponds to the name of the product or service: There's no place like HomeStay (Shape Magazine, November, 2011). For example, in ad of hotel chain HomeStay proverb there's no place like Home was modificated by replacing usual lexical unit home into advertised hotel name.

c) substitution of component by a contextual synonym. When substitutes are in synonymic relationship in the given context, we define substitution as synonymic of contextual type, for example: Think ahead. Manchester Business School (The Economist, June, 2010). From this advertising text we can see that popular set expression think big "have plans that are extremely difficult to perform" became the basis for the transformation. The copywriters, transforming this phraseological unit, retain its original meaning and at the same time update the chliched image and adapt it to the advertising purpose. Despite the fact that occasional modification retains only a key component (usually verb form), and the other components are replaced by a contextual synonym. Phraseological unit does not lose the primary meaning, moreo- 
ver, retains its internal form, that is why, it is easily decoded in the recipients'minds.

d) substitution of component, indicating the use of goods or services. The process depends on the subject of advertising, for example: Driving is believing. Hyundai (Stuff, January, 2012). Staying is believing ... Fairfild Marriott (GQ, December, 2012). These examples show that the original expression seeing is believing can be easily decoded as "only concrete evidence is reliable". In pursuit of the pragmatic effect, the sender attracts recipient's attention to the updated meaning of phraseologisms by means of using substitutes, to create associative links of the advertised product or service. Such kind of a link is clearly observed in advertisement texts of brand Hyundai car and the hotel chain Fairfild Marriott Hotel.

Note should be taken, that in addition to replacing one component in the structure of set expression, the copywriters use the so-called polysubstitution, replacing components that change a "face" of this structure to a maximum effect, for example: Two dabs a day helps keep the surgeon away. Clinically proven to help visibly repair 4 major signs for eye aging. New Plantscription Anty-Aging eye treatment. (Shape Magazine, November, 2011). It can be seen that a saying an apple a day helps keep a doctor away became a basis for substitution [10]. Three key components the copywriters replaced by which respond to authors' idea. Despite the fact that occasional form of set expression given in the text, retains only an usual verb, the set expression does not lose the imagery and preserves the internal form, so easily decoded in recipients' minds.

\section{The results of the research}

The present article has provided insights into creating mechanisms of phraseological transformations in English advertising discourse. The findings of the present research support previous studies on this problem and have provided a detailed analysis on mechanisms of transformations creating.

It was determined that all phraseological transformations can be divided into two types: semantic and structural-semantic. Semantic transformations are formed by mechanisms of dephraseologisation and dual actualization. Structural-semantic transformations are made up by components expansion of original set expression and realized due to enlargement and wedging. Mechanism of compositional components reduction is based on semantics and functioning "narrowing" of language phraseologcal units. This is achieved by means of a device of individual components "truncation".

The substitution of set expression components means a transformation mechanism, which is based on intentional replacement of phraseological unit components with non normative elements. Within substitution devices we single out specific cases of component replacements: substitution of component that corresponds to brand's name or organization, name of the product or service, substitution of component by a contextual synonym, substitution of component, indicating the use of goods or services.

\section{Conclusion}

Our study has shown that the pragmatic effect in English advertising discourse produced by the modifica- tion of phraseological units through semantic and structural-semantic transformations. These transformations require different creating mechanisms which depend on advertising subject or its features. The use of occasional phraseological units in English advertising texts is explained by their ability to define such an object, which can not be expressed by the established use of idioms. Such occasional use of phraseological units in English advertising discourse helps sender persuade recipient to buy goods or use a service.

\section{References}

1. Kuznyeczova, G. V. Strukturno-semantychna variatyvnist frazeologichnyx odynycz $\mathrm{v}$ anglomovnomu xudozhnomu dyskursi: kognityvnyj i pragmatychnyj aspekty (na materiali tvoriv brytanskyx ta amerykanskyj avtoriv XX - XXI stolit) [Text]: avtoref. dys... kand.. filol. nauk / G. V. Kuznyeczova. - Doneczk, 2008. - 25 p.

2. Derev'yanko, V. I. Substytuciya komponentiv yak odyn iz vydiv transformaciyi frazeologizmiv (na materiali cheskoyi ta ukrayinskoyi mov) [Text] / V. I. Derev'yanko // Komparatyvni doslidzhennya slov'yanskyx mov i literature. 2012. - Vol. 18. - P. 43-50.

3. Kulikova, E. V. Reklamnyiy tekst: Lingvisticheskie priemyi vyirazitelnosti [Text] / E. V. Kulikova // Vestnik Nijegorodskogo universiteta im. N. I. Lobachevskogo. - 2009. Vol. 6, Issue 2. - P. 276-282.

4. Martinez, F. M. Occasional Phraseological Synonymy [Text] / F. M. Martinez // International Journal of English Studies (IJES). - 2006. - Vol. 6, Issue 1.

5. Ifill, T. Seeking the Nature of Idioms: A Study in Idiomatic Structure [Electronic resource] / T. Ifill // Available at: https://www.swarthmore.edu/sites/default/files/assets/document s/linguistics/2003_ifill_tim.pdf

6. Kontekstualnoe ispolzovanie frazeologicheskih edinits: kollektivnaya monografiya [Text]: monogr. / A. R. Ab-dulina, R. A. Ayupova, A. O. Zholobova, A. R. Zalyaleeva, S. G. Karimova, R. A. Safina et. al; E. F. Arsenteva (Ed.). - Kazan: Tatarskoe respublikanskoe izdatelstvo «Heter», 2009. - 168 p.

7. Xoroz, N. S. Transformaciyi frazeologizmiv u tekstax suchasny`x xorvats`ky`x gazet [Test]: dy`s... kand. filol. nauk / N. S. Xoroz. - Kyiv, 2008. - 245 p.

8. Kunin, A. V. Kurs frazeologii sovremennogo angliyskogo yazyika [Text] / A. V. Kunin. - Dybna: Feniks+, 2005. $-488 \mathrm{p}$.

9. Free Merriam-Webster Online Dictionary: An Encyclopedia Britannica Company [Electronic resource]. - Available at: http://www.merriam-webster.com/

10. Cook, G. The Discourse of Advertising [Text] / G. Cook. - London and New York: Routledge, 2006. - 256 p.

\section{References}

1. Kuznyeczova, G. V. (2008). Strukturno-semantychna variatyvnist frazeologichnyx odynycz v anglomovnomu xudozhnomu dyskursi: kognityvnyj i pragmatychnyj aspekty (na materiali tvoriv brytanskyx ta amerykanskyj avtoriv XX XXI stolit) [Structural-semantic variations of phraseological units in English art discourse: cognitive and pragmatic aspects (on the pieces of work) of American and British authors of XX - XXI centuries)]. Donetsk, 25.

2. Derev'yanko, V. I. (2012). Substytuciya komponentiv yak odyn iz vydiv transformaciyi frazeologizmiv (na materiali cheskoyi ta ukrayinskoyi mov) [Componential substitution as the basic model of phraseological transformations]. Komparatyvni doslidzhennya slov'yanskyx mov i literature, $18,43-50$.

3. Kulikova, E. V. (2009). Reklamnyiy tekst: Lingvisticheskie priemyi vyirazitelnosti [Advertising text: Linguistic 
expressive devices ]. Vestnik Nijegorodskogo universiteta im. N. I. Lobachevskogo, 6 (2), 276-282.

4. Martinez, F. M. (2006). Occasional Phraseological Synonymy. International Journal of English Studies (IJES), 6 (1).

5. Ifill, T. Seeking the Nature of Idioms: A Study in Idiomatic Structure. Available at: https://www.swarthmore.edu/ sites/default/files/assets/documents/linguistics/2003_ifill_tim.pdf

6. Abdulina, A. R., Ayupova, R. A., Zholobova, A. O., Zalyaleeva, A. R., Karimova, S. G., Safina, R. A. et. al; Arsenteva, E. F. (Ed.) (2009). Kontekstualnoe ispolzovanie frazeologicheskih edinits: kollektivnaya monografiya [Contextual use of phraseological units: multi-authored monograph]. Kazan, Tataric print house «Heter», 168.
7. Xoroz, N. S. (2008). Transformaciyi frazeologizmiv u tekstax suchasnyx xorvatskyx gazet [Phraseological transformations in the contemporary Croatian newspapers]. Kyiv, 245.

8. Kunin, A. V. (2005). Kurs frazeologii sovremennogo angliyskogo yazyika [The course of phraseology of contemporary English]. Dybna: Feniks+, 488.

9. Free Merriam-Webster Online Dictionary: An Encyclopedia Britannica Company. Available at: http://www. merriam-webster.com/

10. Cook, G. (2006). The Discourse of Advertising. London and New York: Routledge, 256.

Рекомендовано до публікації д-р філол. наук, професор Зациний Ю. А. Дата надходження рукопису 16.05.2016

Makedonova Olga, Postgraduate student, Department of theory and practice of translation from English, Zaporizhzhya National University, Zhukovskogo str., 66, Zaporizhzhya, Ukraine, 69600

E-mail: olgamakedonova13@gmail.com 